\title{
Assessment of Quality and Pollution Potential of Groundwater around Dabhaura Area, Rewa District, Madhya Pradesh, India
}

\author{
U. K. Mishra ${ }^{1}$, A. K. Tripathi ${ }^{1}$, Saras Tiwari $^{2} \&$ Ajay Mishra ${ }^{3}$ \\ ${ }^{1}$ Department of Geology, Shriyut P. G. College Gangeo Rewa, Madhya Pradesh, India \\ 2 Department of Chemistry, I. V. P. G. College Jawa Rewa, Madhya Pradesh, India \\ ${ }^{3}$ Department of Geology, Govt. P. G. Science College Rewa, Madhya Pradesh, India \\ Correspondence: U. K. Mishra, Department of Geology, Shriyut P. G. College Gangeo Rewa, 486113, Madhya \\ Pradesh, India. E-mail: umeshicvmmishra2007@rediffmail.com
}

Received: March 1, 2012 Accepted: March 26, 2012 Online Published: July 23, 2012

doi:10.5539/esr.v1n2p249 URL: http://dx.doi.org/10.5539/esr.v1n2p249

\begin{abstract}
The present paper deals with quality and pollution potential of Groundwater of Dabhaura area, Rewa District, Madhya Pradesh. The study area is mainly drained by Jatari river which finally meets to Tons river, a life line of Rewa region. Geologically, the area is occupied by shale and Govindgarh sandstone formations of Upper Vindhyan. A total of 22 groundwater samples from shallow aquifer zone collected in June 2011 and analyzed to see their suitability for drinking and irrigation purposes. The analysed data reflect that the groundwater of the area is moderately hard to very hard, higher amount of total dissolved solids as well as higher concentration of sulphate due to lithology of aquifers. A most of samples are within prescribed limits as suggested by World Health Organisation (WHO) and Indian Standard (ISI) for drinking purpose. The groundwater is mainly $\mathrm{Ca}-\mathrm{Mg}-\mathrm{SO}_{4}-\mathrm{Cl}$ and $\mathrm{Ca}-\mathrm{Mg}-\mathrm{HCO}_{3}$ type. The plot of electrical conductance (EC) vs sodium adsorption ratio (SAR) of analysed groundwater samples in U.S. salinity diagram indicating them to be of medium to high salinity and low sodium hazard type of groundwater. However, for the computation of vulnerability, the DRASTIC Index (DI) modelling has been adopted. The computed Drastic Index suggests that the area is moderate to high susceptible to pollution. Hence, proper attention and water quality monitoring programme has been suggested to check the groundwater pollution.
\end{abstract}

Keywords: groundwater pollution, DRASTIC index, Dabhaura, Madhya Pradesh India

\section{Introduction}

The Groundwater is a precious natural resource which plays a vital role to cater the demand of water supply arising due to inadequate surface water resources throughout the world. The changes are fairly rapid in shallow aquifers because of discharge recharge pattern as well as contaminated activities (Raghunath, 1987). The quality of groundwater is largely controlled by discharge-recharge pattern, nature of host and associated rocks as well as contaminated activities (Walton, 1970). The hydrogeochemical evolution of groundwater is a dynamics process undergoing constant change in space and time (Karanth, 1987). The quality of groundwater is of considerable importance in addition to its quantity for the management of groundwater resource. The study on groundwater quality of Vindhyan region has been performed by few researchers (Tiwari et al., 2009; Tiwari et al., 2010; Mishra, 2010). Hydrogeochemistry and classification of groundwater are carried out in order to evaluate its suitability for municipal, agricultural and industrial uses (Ahmed et al., 2002; Jasrotia \& Singh, 2007; Suresh et al., 2010; Purushottam et al., 2011). Realizing the importance of groundwater quality delineation, the present work has been undertaken around Dabhaura area, a tehsil headquarter in Rewa district, Madhya Pradesh (Figure $1)$. 


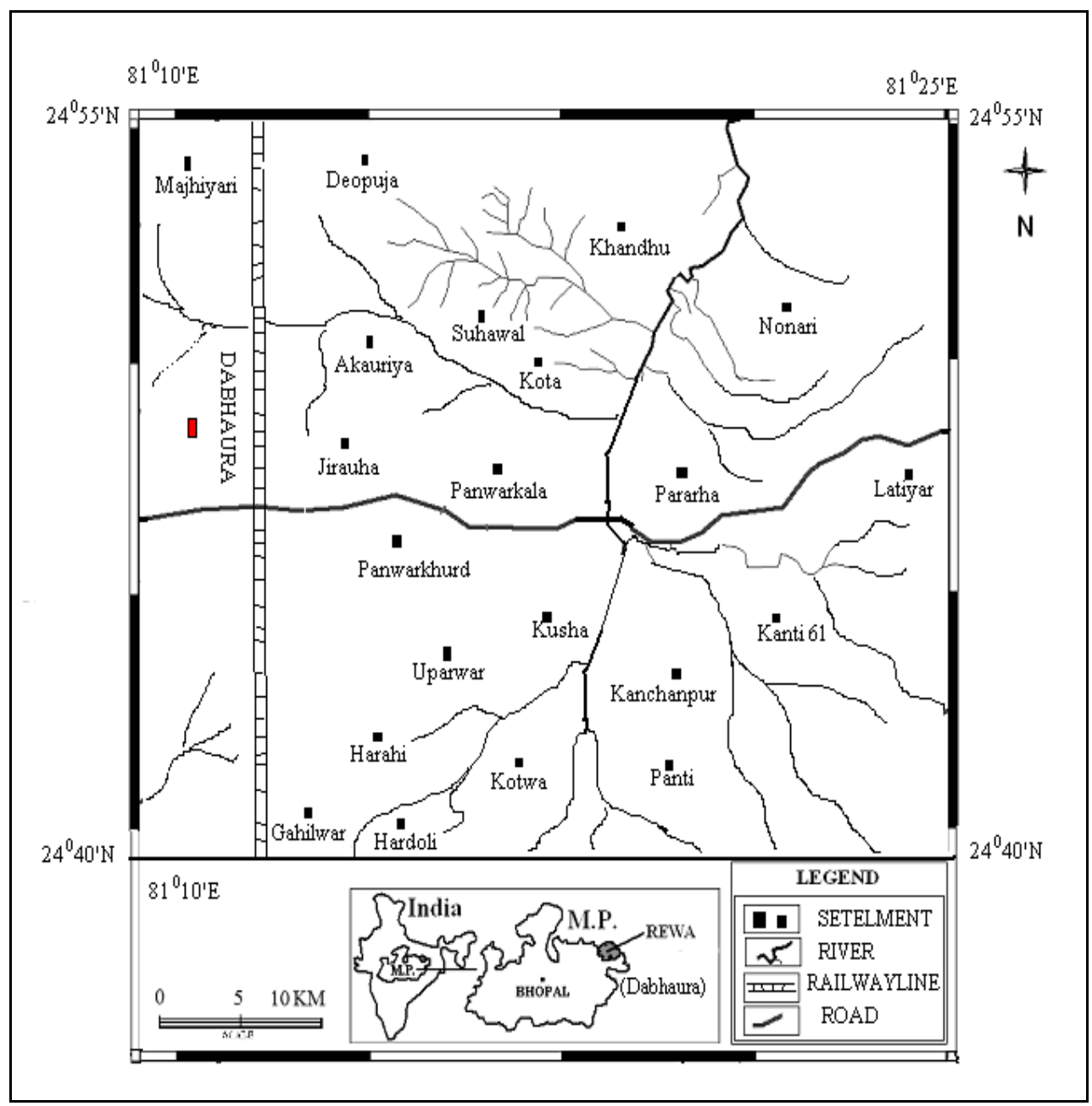

Figure 1. Location map of the Study Area

The study area is drained by Naina river and its tributaries and bounded by latitude $24^{0} 40^{\prime}$ to $24^{0} 55^{\prime} \mathrm{N}$ and logitude $81^{\circ} 10^{\prime}$ to $81^{\circ} 25^{\prime} \mathrm{E}$ covering an area of about $500 \mathrm{~km}^{2}$. The climate is semi arid to humid type and average rainfall of the area is about $1000 \mathrm{~mm}$ however in the year 2010 it was recorded $549 \mathrm{~mm}$. The temperature in summer months goes up to $46^{\circ} \mathrm{C}$ while as low as $2^{\circ} \mathrm{C}$ during peak winter month. The relative humidity is of about 75 percentage.

\section{Geology and Hydrogeology}

The study area is part of northern extension of Vindhyan sedimentary basin; one of the thickest sedimentary basins of India. The main rock types are Govindgarh sandstone and shale of Rewa Group of Vindhyan Supergroup. Besides these, recent alluviums also present in the area. Sandstone is medium to coarse grained, red and brown in colour and dominated by monocrystalline quartz. It is quartz arenite type (Tiwari \& Dubey, 2007) and shows development of cross beds. The shale is thinly bedded and chocolate brown in colour with the development of polygonal mud cracks.

Hydrogeologically, the area is hard rock terrain, lying in Pre-Cambrian sedimentary province (Karanth, 1987). Due to high silica cementation in sandstone, the primary porosity is low. Secondary porosity in the form of joints, fractures, bedding planes and weathered pediments are favourable for the groundwater exploitation. The groundwater occurs in both semi confined and confined conditions.

\section{Methodology}

The present study is based on 22 groundwater samples which collected from Dugwells during June, 2011. The physico-chemical analysis was performed following standard methods (Ramteke \& Moghe, 1986; APHA, 1998). The $\mathrm{pH}$, electrical conductivity and total dissolved solids of the samples were determined in the field using 
portable instruments. Calcium, magnesium, total hardness, sodium, potassium, chloride, bicarbonate, sulphate, and fluoride were determined in the laboratory by folowing standard analygtical technique (APHA, 1998).

The total hardness in groundwater in the study area has been calculated using the formula proposed by Raghunath (1987) as under:

$$
\mathrm{TH} \text { as } \mathrm{CaCO}_{3} \text { in } \mathrm{mg} / \mathrm{l}=(\mathrm{Ca}+\mathrm{Mg}) \mathrm{mg} / \mathrm{l} \times 50
$$

For the computation of DRASTIC Index, some hydrogeological parameters as outlined by Aller et al. (1987) have been used, which are given below:
i. $\quad$ Depth to water table (D)
ii. $\quad$ Net Recharge (R)
iii. Aquifer media (A)
iv. Soil media (S)
v. Topography (T)
vi. Impact of vadose zone and (I)
vii. Hydraulic conductivity of aquifer (C)

$$
\text { D.I. }=D_{R} D_{w}+R_{R} R_{W}+A_{R} A_{w}+S_{R} S_{w}+T_{R} T_{W}+I_{R} I_{W}+C_{R} C_{W}
$$

where R- rating; W- weightage

\subsection{Classification of Groundwater}

The classification of groundwater is essential to know the suitability of groundwater of an area for domestic, agricultural or industrial uses. In the study area, groundwater are classified based on the total dissolved constituents TDS, $\mathrm{Cl}^{-} \mathrm{SO}_{4}^{-2}, \mathrm{HCO}_{3}^{-}$etc. Wilcox (1955) classified groundwater on the basis of concentration of TDS as upto $500 \mathrm{mg} / \mathrm{l}$; desirable for drinking, $500-1000 \mathrm{mg} / \mathrm{l}$; permissible for drinking, upto $3000 \mathrm{mg} / \mathrm{l}$; useful for irrigation and $>3000 \mathrm{mg} / \mathrm{l}$; unfit for drinking and irrigation. Based on the above classification, about $45 \%$ of the samples are within the desirable limit and $55 \%$ are in permissible limit for drinking purpose.

The maximum sulphate concentration in the water samples is $315.30 \mathrm{mg} / \mathrm{l}$ (sandstone) while the concentration in shale formation is $612.00 \mathrm{mg} / \mathrm{l}$ in water sample (Table 1). This suggests that $65 \%$ of the water sample belong to the "normal sulphate" category (Schoeller, 1962). Based on this classification, the groundwater of the area has maximum concentration of chloride is $85.00 \mathrm{mg} / \mathrm{l}$ in sandstone and 212.00 in shale indicates that the groundwater is "normal chloride" water (Schoeller, 1962). The minimum total hardness concentration in groundwater in the study area is $100 \mathrm{mg} / \mathrm{l}$ and the maximum concentration is $802 \mathrm{mg} / \mathrm{l}$. According to classification based on hardness scale by USGS (Hem, 1985), the groundwater of the area is moderately hard to very hard. The minimum $\mathrm{HCO}_{3}^{-}$concentration in groundwater in the study area is $109.00 \mathrm{mg} / \mathrm{l}$ in while the maximum concentration is $365.00 \mathrm{mg} / \mathrm{l}$ observed in thus, most of the groundwater samples belong to the normal carbonate category (Schoeller, 1962).The analyzed data has been plotted on Chadha's (1999) diagram which is modified version of Piper's (1953) trilinear diagram. It has all the advantage on the diamond shaped field of the Piper's trilinear and can be also used to study various hydro-chemical processes such as base cation exchange, actual ion concentration, mixing of natural waters and sulphate reduction and other related hydro-chemical problems.

In the Chadha's scheme the difference in milliequivalent (epm) percent between alkaline earth (Calcium + Magnesium) and alkali (Sodium + Potassium) expressed as percentage reacting value is plotted on the X-axis and difference in milliequivalent (epm) percentage between weak acid anion (Carbonate + Bicarbonate) and strong acid anion (Chloride + Sulphate + Nitrate) is plotted on the Y-axis. The milliequivalent percentage difference between alkaline earth and alkaline metals and between weak acidic anions and strong acidic anions would plot in one of the four possible subfields of the diagram. In the study area, out of 22 groundwater samples, 12 sandstone samples and 07 shale samples fall in the subfield -5 of $\mathrm{Ca}-\mathrm{Mg}-\mathrm{HCO}_{3}$ type whereas 02 sandstone samples and 01 shale samples fall in the subfield 6 indicating $\mathrm{Ca}-\mathrm{Mg}-\mathrm{Cl}-\mathrm{SO}_{4}$ type (Figure 2). 


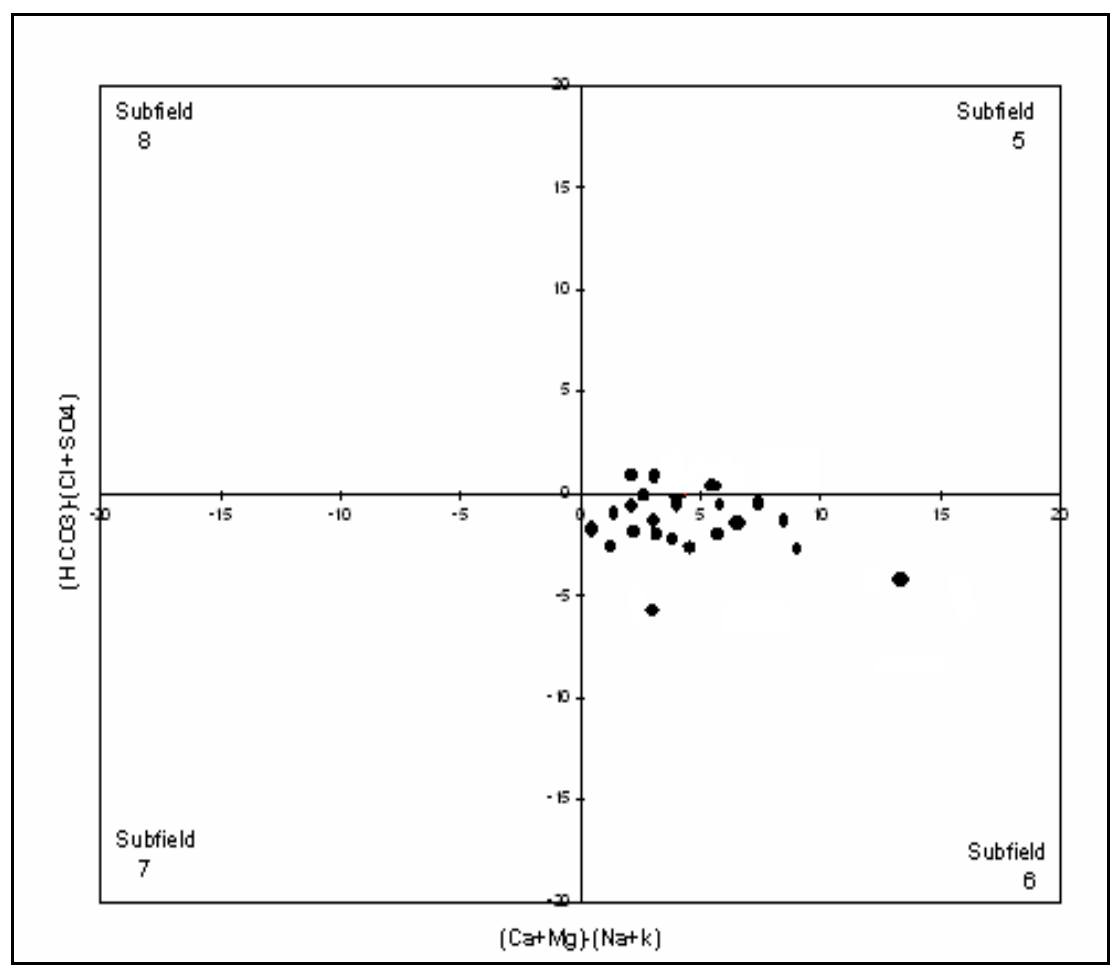

Figure 2. Classification of Groundwater samples as Per Chadha's (1999) Scheme

\section{Results and Discussion}

\subsection{Drinking Water Quality}

As evident from Table 1, $\mathrm{pH}$ ranges from 7.4 to 8.9 indicating alkaline nature of groundwater. The higher $\mathrm{pH}$ values observed in certain samples suggest that carbon dioxide, carbonate-bicarbonate equilibrium is affected more due to change in physico-chemical conditions (Karanth, 1987; Tiwari et al., 2010).

The conductivity of groundwater sample of the study area varies from $500 \mathrm{mg} / \mathrm{l}$ to $1867 \mathrm{mg} / \mathrm{l}$ in shale. Higher concentration of electrical conductance in shale may be due to the enough time for reaction between groundwater sample and impervious shale. The sandstone litho units have comparatively lesser amount of EC due to its hydrological characters. The total dissolved solids (TDS) varies between $321 \mathrm{mg} / 1$ to $1197 \mathrm{mg} / \mathrm{l}$. The water with TDS upto $1000 \mathrm{mg} / \mathrm{l}$ is considered to be suitable for drinking (Pophare \& Dewalkar, 2007; Tiwari \& Singh, 2010). The higher amount of TDS may cause gastrointestional irritation in human body.

The total hardness varies between $100 \mathrm{mg} / \mathrm{l}$ (Kanchanpur; moderately soft) to $802 \mathrm{mg} / \mathrm{l}$ (Pararha; very hard). The possibility of groundwater hardness in the area may be due to calcareous sandstone. The content of calcium in sandstone aquifers varies from $15 \mathrm{mg} / 1$ to $109 \mathrm{mg} / \mathrm{l}$ while in shale, the range of concentration varies from 30 $\mathrm{mg} / \mathrm{l}$ to $99.2 \mathrm{mg} / \mathrm{l}$. The magnesium concentration in water sample from sandstone ranges $11.5 \mathrm{mg} / \mathrm{l}$ to $75 \mathrm{mg} / \mathrm{l}$ while in shales, the concentration varies $16 \mathrm{mg} / 1$ to $177 \mathrm{mg} / \mathrm{l}$. The concentration of sodium ranges from $5 \mathrm{mg} / \mathrm{l}$ to $104 \mathrm{mg} / 1$ in sandstone aquifers whereas it varies from $19.9 \mathrm{mg} / 1$ to $70 \mathrm{mg} / \mathrm{l}$ in shale lithounit. Similarly, concentration of potassium varies between $1.2 \mathrm{mg} / \mathrm{l}$ to $13.6 \mathrm{mg} / \mathrm{l}$ in sandstone and $1.1 \mathrm{mg} / \mathrm{l}$ to $11.24 \mathrm{mg} / \mathrm{l}$ in shale formations. It seems that the clay minerals present in sandstone and shales contributed these two constituents to the groundwater of the area. In the present study, the groundwater sample from sandstone have sulphate concentration ranging from $4.5 \mathrm{mg} / 1$ to $315.3 \mathrm{mg} / \mathrm{l}$ while in the case of water samples from shaly aquifers, the concentration range of sulphate varies from $20.20 \mathrm{mg} / \mathrm{l}$ to $612 \mathrm{mg} / \mathrm{l}$. The higher concentration of sulphate is due to the gypsum and baryte nodules associated with shale.

The concentration of chloride in sandstone aquifer varying from $20.2 \mathrm{mg} / 1$ to $85 \mathrm{mg} / \mathrm{l}$ while the water samples from aquifer in shale have chloride concentration ranging between $36.66 \mathrm{mg} / \mathrm{l}$ to $212 \mathrm{mg} / \mathrm{l}$. The water samples from sandstone aquifers have bicarbonate ions ranging between $125 \mathrm{mg} / \mathrm{l}$ to $309 \mathrm{mg} / \mathrm{l}$ while the shale formation have the range of bicarbonate ions between $109 \mathrm{mg} / 1$ to $365 \mathrm{mg} / 1$. Potable water should have 0.6 to $1 \mathrm{mg} / \mathrm{lof}$ fluoride for substantial protection against tooth decay. If fluoride is totally absent in drinking water, it causes 
dental caries. Continuous high intake of fluoride result in mottled teeth, skeletal fluorosis and sometimes severe osteosclerosis. In the study area, the concentration of fluoride ranges from 0.02 to 1.03 in sandstone aquifer whereas 0.01 to 2.7 in shale aquifers. The higher concentration of fluoride in shale formation is due to the presence of $\mathrm{F}^{-}$bearing minerals (biotitic and clay minerals) in shale formation as well as leaching action from other sources. As evident from Table 1, higher concentration of fluoride is strongly related with $\mathrm{pH}$ indicating that higher alkalinity of the water promotes the leaching of $\mathrm{F}^{-}$and thus affects the concentration of $\mathrm{F}^{-}$in the groundwater (Chatterjee et al., 2008, Duraiswamy \& Patankar, 2011; Saxena \& Ahmed, 2001; Madhnure et al., 2007). To ascertain the suitability of groundwater for drinking purpose the geochemical parameters of the study area are compared with the guidelines as recommended by WHO (1984) and ISI (1991) which indicate that groundwater of the study area is more or less suitable for drinking purpose (Table 2).

Table 1. Geochemical analyses of groundwater samples of the study area

\begin{tabular}{|c|c|c|c|c|c|c|c|c|c|c|c|c|c|}
\hline Lithology & Location & $\mathrm{P}^{\mathrm{H}}$ & $\begin{array}{c}\mathrm{EC} \\
(\mu \mathrm{s} / \mathrm{cm})\end{array}$ & TDS & $\mathrm{TH}$ & $\mathrm{Na}$ & $\mathrm{K}$ & $\mathrm{Ca}$ & $\mathrm{Mg}$ & $\mathrm{F}$ & $\mathrm{Cl}$ & $\mathrm{SO}_{4}$ & $\mathrm{HCO}_{3}$ \\
\hline 1 & 2 & 3 & 4 & 5 & 6 & 7 & 8 & 9 & 10 & 11 & 12 & 13 & 14 \\
\hline SSt./1 & DABHAURA & 7.6 & 757 & 485 & 352 & 27.32 & 12.41 & 109.00 & 19.01 & 1.03 & 81.02 & 50.16 & 309.00 \\
\hline SSt./2 & GAHILWAR & 8.1 & 507 & 325 & 465 & 20.00 & 1.20 & 63.00 & 75.00 & 0.09 & 85.00 & 20.00 & 125.00 \\
\hline SSt./3 & HARHAI & 7.5 & 702 & 450 & 352 & 28.30 & 12.30 & 108.00 & 20.00 & 1.00 & 80.00 & 49.10 & 308.00 \\
\hline SSt./4 & MAJHIYARI & 7.6 & 863 & 553 & 293 & 11.50 & 8.40 & 98.30 & 11.50 & 0.30 & 20.20 & 315.30 & 179.00 \\
\hline SSt./5 & KOTWA & 8.2 & 607 & 389 & 123 & 5.00 & 13.40 & 27.49 & 27.49 & 1.00 & 27.60 & 56.90 & 242.80 \\
\hline SSt./6 & KANCHANPUR & 8.2 & 501 & 321 & 100 & 104.00 & 13.60 & 15.00 & 15.09 & 0.50 & 33.10 & 54.50 & 142.20 \\
\hline SSt./7 & DEOPUJA & 7.4 & 605 & 388 & 352 & 37.80 & 2.50 & 92.80 & 29.16 & 1.01 & 57.12 & 6.50 & 132.00 \\
\hline SSt./8 & AKAURIYA & 8.1 & 505 & 324 & 241 & 17.09 & 3.00 & 58.00 & 23.32 & 0.30 & 29.70 & 6.50 & 176.00 \\
\hline SSt./9 & JIRAUHA & 8.3 & 583 & 374 & 315 & 32.00 & 2.80 & 85.00 & 25.00 & 1.01 & 40.00 & 8.90 & 165.00 \\
\hline SSt./10 & KOTA & 8.5 & 1126 & 722 & 305 & 50.00 & 1.24 & 76.00 & 28.05 & 0.02 & 70.12 & 4.50 & 180.00 \\
\hline $\mathrm{Sh} / 11$ & SUHAWAL & 7.7 & 934 & 599 & 323 & 33.10 & 3.08 & 86.20 & 23.30 & 1.40 & 41.10 & 19.90 & 166.10 \\
\hline $\mathrm{Sh} / 12$ & PANWARKALA & 7.6 & 1026 & 658 & 372 & 51.20 & 2.10 & 96.10 & 57.11 & 0.06 & 56.20 & 21.80 & 182.10 \\
\hline $\mathrm{Sh} / 13$ & KHANDHU & 8.1 & 1025 & 657 & 388 & 56.10 & 2.12 & 99.20 & 28.18 & 0.01 & 60.10 & 22.40 & 156.20 \\
\hline $\mathrm{Sh} / 14$ & UPARWAR & 8.0 & 554 & 355 & 367 & 47.15 & 3.20 & 94.30 & 24.20 & 1.00 & 66.20 & 20.20 & 168.30 \\
\hline $\mathrm{Sh} / 15$ & KUSHA & 7.6 & 472 & 303 & 349 & 35.10 & 4.15 & 90.20 & 34.20 & 1.80 & 49.20 & 20.20 & 140.40 \\
\hline $\mathrm{Sh} / 16$ & NONARI & 7.8 & 1221 & 783 & 618 & 19.90 & 2.00 & 79.40 & 102.40 & 0.90 & 39.60 & 407.90 & 270.00 \\
\hline $\mathrm{Sh} / 17$ & HARDOLI & 8.9 & 1126 & 722 & 305 & 50.00 & 11.24 & 76.00 & 28.05 & 2.70 & 70.12 & 405.00 & 188.00 \\
\hline $\mathrm{Sh} / 18$ & PANWARKHURD & 7.7 & 1248 & 800 & 218 & 20.90 & 1.10 & 60.50 & 29.40 & 1.40 & 36.66 & 490.90 & 268.01 \\
\hline $\mathrm{Sh} / 19$ & PANTI & 8.2 & 906 & 581 & 271 & 70.00 & 11.00 & 82.10 & 16.00 & 1.50 & 64.00 & 159.10 & 365.00 \\
\hline $\mathrm{Sh} / 20$ & KANTI 61 & 8.1 & 663 & 425 & 465 & 20.00 & 1.20 & 63.00 & 75.00 & 1.60 & 85.00 & 250.00 & 109.00 \\
\hline $\mathrm{Sh} / 21$ & PARARHA & 7.7 & 1867 & 1197 & 802 & 76.00 & 3.00 & 30.00 & 177.00 & 0.90 & 212.00 & 612.00 & 178.00 \\
\hline $\mathrm{Sh} / 22$ & LATIYAR & 7.6 & 1171 & 751 & 314 & 51.40 & 2.12 & 76.20 & 30.05 & 0.09 & 72.30 & 405.00 & 190.20 \\
\hline
\end{tabular}




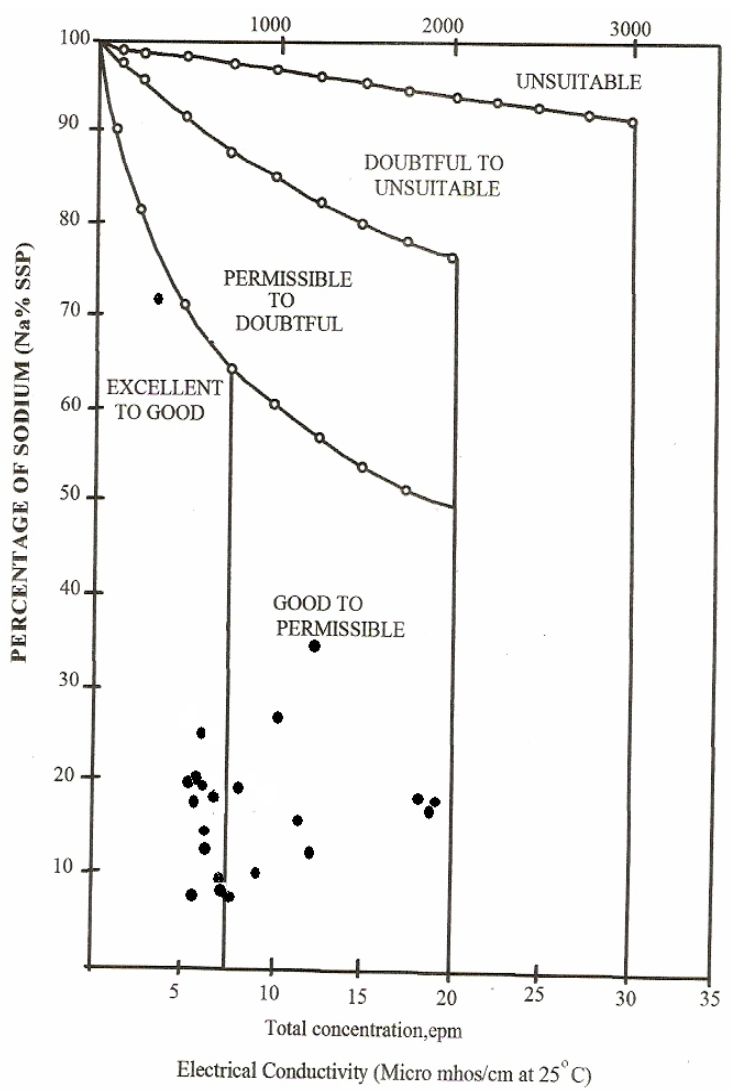

Figure 3. Plot of Sodium percent vs. Electrical conductivity (after Wilcox, 1955)

Table 2. Comparison of the quality parameters of groundwater of the study area with WHO and ISI for drinking purpose

\begin{tabular}{|c|c|c|c|c|c|c|c|}
\hline \multirow{2}{*}{$\begin{array}{l}\text { S. } \\
\text { No. }\end{array}$} & \multirow{2}{*}{$\begin{array}{l}\text { Water Quality } \\
\text { Parameters }\end{array}$} & \multicolumn{2}{|c|}{ WHO (1984) } & \multicolumn{2}{|c|}{ ISI (1991) } & \multirow[b]{2}{*}{$\begin{array}{l}\text { Concentration in } \\
\text { Study Area }\end{array}$} & \multirow{2}{*}{$\begin{array}{l}\text { Undesirable Effect Produced } \\
\text { Beyond Maximum Allowable } \\
\text { Limit }\end{array}$} \\
\hline & & $\begin{array}{c}\text { Highest } \\
\text { Desirable }\end{array}$ & $\begin{array}{l}\text { Max. Per } \\
\text { missible }\end{array}$ & $\begin{array}{c}\text { Highest } \\
\text { Desirable }\end{array}$ & $\begin{array}{l}\text { Max. Per } \\
\text { missible }\end{array}$ & & \\
\hline 1. & $\mathrm{pH}$ & 7.0 to 8.5 & 6.5 to 9.2 & 6.5 to 8.5 & $\begin{array}{c}\text { No } \\
\text { relaxation }\end{array}$ & 7.4 to 8.9 & $\begin{array}{l}\text { Taste, effects mucus memberane } \\
\text { and water supply system. }\end{array}$ \\
\hline 2. & $\begin{array}{c}\mathrm{TH} \\
\mathrm{mg} / \mathrm{l}\end{array}$ & 100 & 500 & 300 & 600 & 100 to 802 & $\begin{array}{l}\text { Encrustation in water supply and } \\
\text { adverse effect on domestic use. }\end{array}$ \\
\hline 3. & $\begin{array}{l}\mathrm{TDS} \\
\mathrm{mg} / \mathrm{l}\end{array}$ & 500 & 1500 & 500 & 1000 & 321 to 1197 & Gastrointestinal irritation. \\
\hline 4. & $\begin{array}{c}\mathrm{Ca} \\
\mathrm{mg} / \mathrm{l}\end{array}$ & 75 & 200 & 75 & 200 & 15 to 109 & $\begin{array}{l}\text { Encrustation in water supply, } \\
\text { scale formation. }\end{array}$ \\
\hline 5. & $\begin{array}{l}\mathrm{Mg} \\
\mathrm{mg} / 1\end{array}$ & 30 & 150 & 30 & 100 & 11.5 to 177 & $\begin{array}{l}\text { Encrustation in water supply and } \\
\text { adverse effect on domestic use. }\end{array}$ \\
\hline 6. & $\begin{array}{c}\mathrm{Na} \\
\mathrm{mg} / \mathrm{l}\end{array}$ & - & 200 & - & 200 & 5 to 104 & -- \\
\hline 7. & $\begin{array}{c}\mathrm{Cl} \\
\mathrm{mg} / \mathrm{l}\end{array}$ & 200 & 600 & 250 & 1000 & 20.2 to 212 & Salty Taste \\
\hline 8. & $\begin{array}{l}\mathrm{SO}_{4} \\
\mathrm{mg} / 1\end{array}$ & 200 & 400 & 150 & 400 & 4.5 to 612 & Laxative effect \\
\hline 9. & $\mathrm{~F} \mathrm{mg/l}$ & 0.6 to 0.9 & 0.8 to 1.7 & 1.00 & 1.5 & 0.01 to 2.70 & $\begin{array}{l}\text { Excessive fluoride causes } \\
\text { skeletal and dental fluorosis in } \\
\text { both children and adult }\end{array}$ \\
\hline
\end{tabular}




\subsection{Irrigation Water Quality}

In the present study the irrigation water quality has been evaluated on the basis of following criteria:

\section{Sodium Percentage $(\mathrm{Na} \%)$}

It is an important parameter to classify the groundwater samples for irrigation purpose. It is calculated by the formula proposed by Doneen (1962) as under:

$$
\mathrm{Na} \%=\frac{\mathrm{Na}^{+}+K^{+}}{\mathrm{Ca}^{++}+\mathrm{Mg}^{++}+\mathrm{Na}^{+}+K^{+}} \times 100
$$

Sodium along with carbonate forms alkaline soil; while sodium with chloride forms saline soil; both of these are not suitable for the growth of plants (Pandian \& Shankar, 2007). The quality classification of irrigation water based on the values of sodium percentage as proposed by Wilcox (1955) suggest that $55 \%$ samples are excellent to good category whereas $45 \%$ samples are good to permissible category.

\subsubsection{Electrical Conductivity (EC)}

It measures the capacity of substance or solution to conduct electric current. The EC of groundwater increases with the rise in temperature and varies with the amount of TDS. The conductivity in the groundwater samples of the area ranges from 472 to $1867 \mu \mathrm{s} / \mathrm{cm}$ at $25^{\circ} \mathrm{C}$ indicating good category of irrigation water.

\subsubsection{Sodium Adsorption Ratio (SAR)}

The degree to which the irrigation water tends to enter into cation exchange reaction in soil can be indicated by the sodium adsorption ratio (U.S. Salinity, 1954). Since sodium replaces adsorbed calcium and magnesium in soil, hence it is expressed as:

$$
\mathrm{SAR}=\frac{\mathrm{Na}^{+}}{\sqrt{\mathrm{Ca}^{++}+M g^{++} / 2}}(\text { epm })
$$

Excess sodium in groundwater gets adsorbed on soil particles, thus change soil properties and also reduce soil permeability (Ayers \& Bronson, 1975). U.S. Salinity Laboratory (1954) proposed to plot SAR against EC for rating irrigation water. The sixteen classes in the diagram indicate the extent that the waters can effect the soil in terms of salinity hazard. These classes are: low salinity $\left(\mathrm{C}_{1}\right)$, medium $\left(\mathrm{C}_{2}\right)$, high $\left(\mathrm{C}_{3}\right)$ and very high salinity $\left(\mathrm{C}_{4}\right)$ and similarly sodium hazard as low $\left(\mathrm{S}_{1}\right)$, medium $\left(\mathrm{S}_{2}\right)$, high $\left(\mathrm{S}_{3}\right)$ and very high $\left(\mathrm{S}_{4}\right)$. The groundwater samples of the study area fall in $\mathrm{C}_{3} \mathrm{~S}_{1}\left(8\right.$ samples) and $\mathrm{C}_{2} \mathrm{~S}_{1}(14$ samples) categories, hence suitable for irrigation purpose and indicate that most of the groundwater samples of the study area are medium to high saline and low sodium hazard zone. Hence high salinity water should be used only in those soils where adequate drainage is available to leach out the excessive water.

As per classification of Wilcox (1955), water with SAR $\leq 10$ is considered as an excellent quality, between 10 to 18 is good; between 18 to 26 is fair and greater than 26 is said to be unsuitable for irrigation purpose in its natural form. As evident from Table 3, all groundwater samples possess $\leq 10 \mathrm{SAR}$; hence excellent for irrigation purpose.

\subsubsection{Kelley's Ratio (KR)}

It is the ratio of sodium ion to calcium and magnesium ion in epm (Kelley, 1951) and expressed as:

$$
\mathrm{K} . \mathrm{R} .=\frac{N a^{+}}{\mathrm{Ca}^{++}+M g^{++}}(\text {epm })
$$

The Kelley's Ratio (KR) have been computed for all groundwater samples of the study area and presented in (Table 3). In the study area KR ranges from 0.06 to 2.28 indicating that water is suitable for irrigation purpose as the value is less than 2.5 .

\subsubsection{Permeability Index (PI)}

The classification of irrigation waters has been attempted on the basis of permeability Index, as suggested by Doneen (1962). It is defined as: 


$$
\text { P.I. }=\frac{\mathrm{Na}^{+}+\sqrt{\mathrm{HCO}_{3}^{-}}}{\mathrm{Ca}^{++}+\mathrm{Mg}^{++}+\mathrm{Na}^{+}} \times 100(\mathrm{epm})
$$

The groundwater samples of the study area fall in class-I. As per Doneen chart (Domenico \& Schwartz, 1990), the groundwater samples of the study area is of good quality for irrigation (Figure 5). The increased percentage of groundwater samples under class-I is due to dilution subsequent lower values of permeability index.

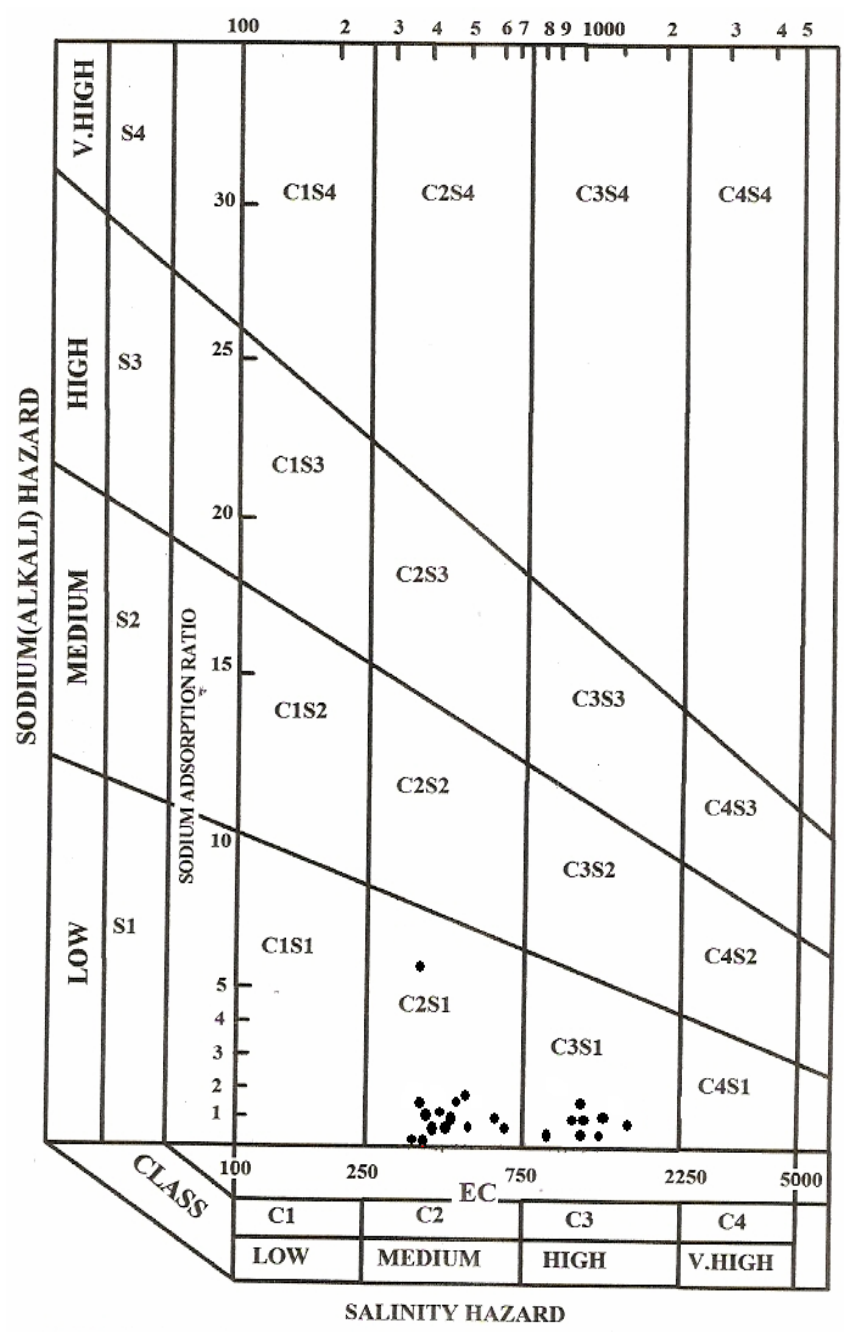

Figure 4. U.S. Salinity Diagram for classification of irrigation groundwater (after Richards, 1954)

Table 3. Ratio and indices of groundwater samples of the study Area

\begin{tabular}{llccccccc}
\hline S.No. & No. of Location & SAR & KR & SSP & MR & CR & PI & RSC \\
\hline \multicolumn{1}{c}{ 1 } & \multicolumn{1}{c}{2} & 3 & 4 & \multicolumn{1}{c}{5} & 6 & 7 & 8 & 9 \\
\hline 1. & DABHAURA & 0.90 & 0.17 & 17.70 & 22.33 & 0.06 & 42.00 & -1.94 \\
2. & GAHILWAR & 0.57 & 0.09 & 8.82 & 66.24 & 0.07 & 22.59 & -7.26 \\
3. & HARHAI & 0.93 & 0.18 & 18.01 & 23.39 & 1.06 & 42.04 & -1.99 \\
4. & MAJHIYARI & 0.41 & 0.09 & 10.89 & 16.17 & 0.02 & 34.77 & -2.92 \\
5. & KOTWA & 0.24 & 0.06 & 13.72 & 62.24 & 0.02 & 57.64 & 0.35 \\
6. & KANCHANPUR & 6.59 & 2.28 & 71.06 & 62.24 & 0.03 & 93.05 & 0.34 \\
7. & DEOPUJA & 1.24 & 0.23 & 19.55 & 34.12 & 0.05 & 24.91 & -4.87 \\
\hline
\end{tabular}




\begin{tabular}{llrrrrrrr}
\hline 8. & AKAURIYA & 0.67 & 0.15 & 14.56 & 39.86 & 0.02 & 90.93 & -1.93 \\
9. & JIRAUHA & 1.11 & 0.22 & 18.86 & 32.65 & 0.03 & 39.44 & -3.59 \\
10. & KOTA & 1.77 & 0.36 & 26.57 & 37.83 & 1.06 & 47.07 & -3.15 \\
11. & SUHAWAL & 1.16 & 0.23 & 19.63 & 30.82 & 0.03 & 40.32 & -3.50 \\
12. & PANWARKALA & 1.44 & 0.23 & 19.37 & 49.49 & 0.04 & 33.72 & -6.51 \\
13. & KHANDHU & 1.82 & 0.34 & 25.55 & 31.89 & 0.05 & 41.60 & -4.71 \\
14. & UPARWAR & 1.58 & 0.31 & 24.16 & 29.73 & 0.05 & 42.41 & -3.94 \\
15. & KUSHA & 1.13 & 0.21 & 18.25 & 38.46 & 0.04 & 34.46 & -5.01 \\
16. & NONARI & 0.49 & 0.07 & 6.89 & 68.01 & 0.04 & 22.45 & -7.96 \\
17. & HARDOLI & 1.77 & 0.36 & 28.76 & 37.83 & 0.06 & 47.52 & -3.02 \\
18. & PANWARKHURD & 0.78 & 0.17 & 14.70 & 44.48 & 0.03 & 47.32 & -1.04 \\
19. & PANTI & 2.62 & 0.56 & 38.06 & 24.32 & 0.05 & 64.88 & 0.57 \\
20. & KANTI 61 & 0.57 & 0.09 & 8.82 & 66.24 & 0.07 & 21.72 & -7.51 \\
21. & PARARHA & 1.65 & 0.21 & 17.37 & 90.70 & 0.17 & 25.87 & -13.17 \\
22. & LATIYAR & 1.79 & 0.36 & 26.74 & 39.40 & 1.06 & 47.07 & -3.16 \\
\hline
\end{tabular}

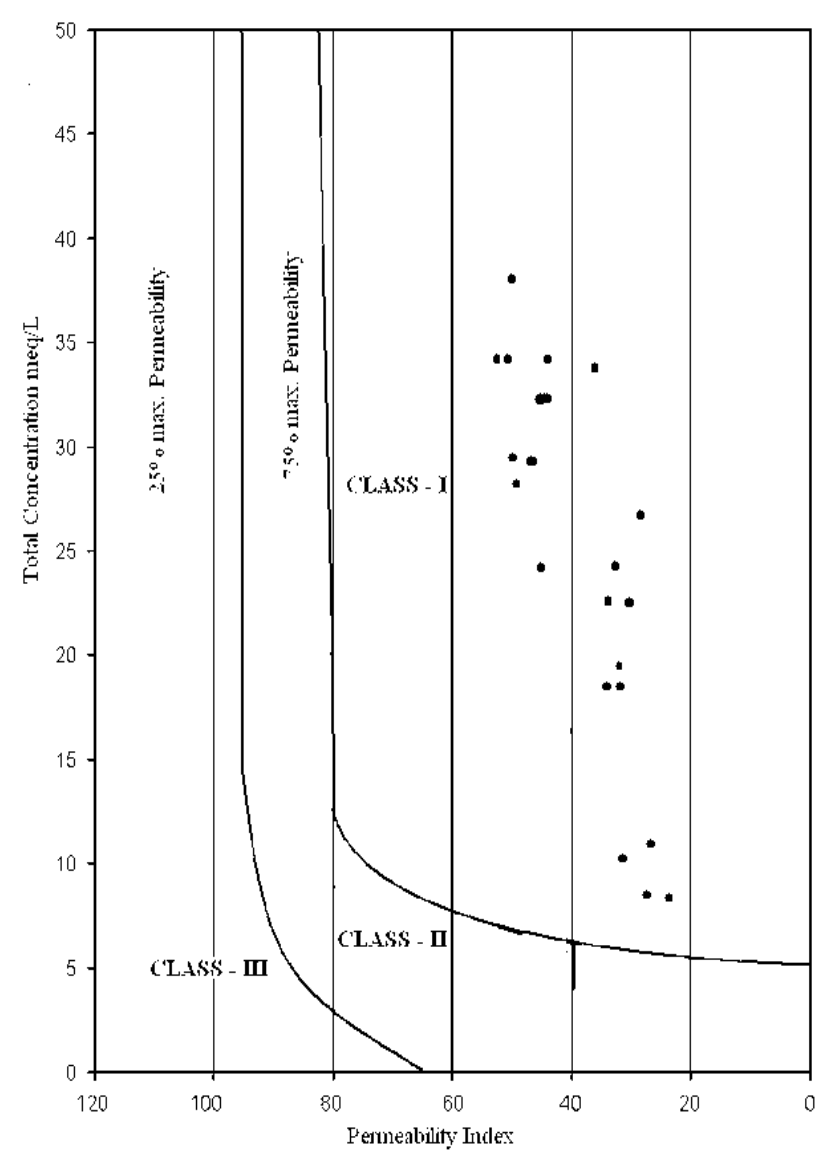

Figure 5. Classification of irrigation water (Doneen, 1962)

4.2.5 Magnesium Ratio (MR)

It is expressed as:

$$
\text { M.R.. }=\frac{M g^{+}}{\mathrm{Ca}^{++}+M g^{++}} \times 100(\text { epm })
$$


If the Magnesium Ratio is greater than 50\%; it is considered as suitable for irrigation purpose (Palliwal, 1972). In the present study $70 \%$ samples are good for irrigation whereas $30 \%$ samples are unsuitable (Table 3 ).

\subsubsection{Residual Sodium Carbonate (RSC)}

It refers to the residual alkalinity and is calculated for irrigation water by the following formula:

$$
\mathrm{RSC}=\left(\mathrm{HCO}_{3}^{-}+\mathrm{CO}_{3}^{--}\right)-\left(\mathrm{Ca}^{++}+\mathrm{Mg}^{++}\right)(\mathrm{epm})
$$

The RSC values $>1.25 \mathrm{mg} / 1$ are considered as safe for irrigation while those from $1.25 \mathrm{mg} / \mathrm{l}$ to $2.5 \mathrm{mg} / \mathrm{lare}$ marginally suitable for irrigation. If RSC values are $>2.5$, the groundwater is unsuitable for irrigation (Eaton, 1950; Richards, 1954). The RSC values of groundwater samples of the study area ranges from $-13.17 \mathrm{mg} / \mathrm{l}$ (Pararha) to $+0.57 \mathrm{mg} / \mathrm{l}$ (Panti); hence suitable for irrigation purpose.

\subsubsection{Corrosivity Ratio (CR)}

It is defined as alkaline earth and alkalies and expressed as:

$$
\text { C.R. }=\frac{\mathrm{Cl}^{-} / 35.5+2\left(\frac{\mathrm{SO}_{4}^{--}}{96}\right)}{2\left(\frac{\mathrm{HCO}_{3}^{-}+\mathrm{CO}_{3}^{--}}{100}\right)}
$$

The groundwater with corrosivity ratio $<1$ is considered to be safe for transport of water in any type of pipes, whereas $>1$ indicate corrosive nature and hence not to be transported through metal pipes (Ryner, 1944, Raman, 1985). The calculated values of groundwater samples of the study are presented in Table-1.3, which suggests that 19 samples are safe whereas 3 samples are corrosive in nature and need non-corrosive pipe for transporting and lifting of groundwater.

\subsection{Pollution Susceptibility}

For the estimation of pollution susceptibility, DRASTIC modelling proposed by Aller et al. (1987) has beed adopted. The DRASTIC approach takes into account seven hydrogeologic parameters which influence pollution of the area. The index of vulnerability is computed through multiplication of the value attributed to each parameter by its relative weight and adding up all seven products (Table 4).

$$
\text { DRASTIC INDEX }=5 \times \mathrm{D}+4 \times \mathrm{R}+3 \times \mathrm{A}+2 \times \mathrm{S}+1 \times \mathrm{T}+5 \times 1+3 \times \mathrm{C}
$$

\begin{tabular}{|c|c|c|c|c|c|c|c|c|c|}
\hline S.N. & $\begin{array}{l}\text { Location } \\
\text { Weightage }\end{array}$ & $\begin{array}{l}\text { Depthto } \\
\text { water table } \\
5\end{array}$ & $\begin{array}{l}\text { Recharge } \\
4\end{array}$ & $\begin{array}{c}\text { Aquifer } \\
\text { Media } \\
3\end{array}$ & $\begin{array}{l}\text { Soil } \\
\text { Media } \\
2\end{array}$ & $\begin{array}{c}\text { Topography } \\
1\end{array}$ & $\begin{array}{l}\text { Impact of } \\
\text { vadose zone } \\
5\end{array}$ & $\begin{array}{l}\text { Hydraulic } \\
\text { conductivity } \\
3\end{array}$ & $\begin{array}{l}\text { Total } \\
\text { Drastic } \\
\text { Number }\end{array}$ \\
\hline 1. & DABHAURA & $9 \times 5=45$ & $9 \times 4=36$ & $8 \times 3=24$ & $7 \times 2=14$ & $9 \times 1=9$ & $8 \times 5=40$ & $8 \times 3=24$ & 192 \\
\hline 2. & GAHILWAR & $8 \times 5=40$ & $6 \times 4=24$ & $6 \times 3=18$ & $6 \times 2=12$ & $10 \times 1=10$ & $3 \times 5=15$ & $6 \times 3=18$ & 137 \\
\hline 3. & HARHAI & $5 \times 5=25$ & $3 \times 4=12$ & $7 \times 3=21$ & $8 \times 2=16$ & $10 \times 1=10$ & $5 \times 5=25$ & $5 \times 3=15$ & 124 \\
\hline 4. & MAJHIYARI & $8 \times 5=40$ & $5 \times 4=20$ & $5 \times 3=15$ & $5 \times 2=10$ & $10 \times 1=10$ & $3 \times 5=15$ & $6 \times 3=18$ & 128 \\
\hline 5. & KOTWA & $6 \times 5=30$ & $3 \times 4=12$ & $6 \times 3=18$ & $8 \times 2=16$ & $10 \times 1=10$ & $6 \times 5=30$ & $6 \times 3=18$ & 134 \\
\hline 6. & KANCHANPUR & $8 \times 5=40$ & $7 \times 4=28$ & $8 \times 3=24$ & $7 \times 2=14$ & $10 \times 1=10$ & $6 \times 5=30$ & $8 \times 3=24$ & 170 \\
\hline 7. & DEOPUJA & $6 \times 5=30$ & $7 \times 4=24$ & $9 \times 3=27$ & $10 \times 2=20$ & $9 \times 1=9$ & $6 \times 5=30$ & $7 \times 3=21$ & 140 \\
\hline 8. & AKAURIYA & $10 \times 5=50$ & $6 \times 4=24$ & $9 \times 3=27$ & $6 \times 2=12$ & $10 \times 1=10$ & $4 \times 5=20$ & $8 \times 3=24$ & 167 \\
\hline 9. & JIRAUHA & $8 \times 5=40$ & $5 \times 4=20$ & $5 \times 3=15$ & $5 \times 2=10$ & $10 \times 1=10$ & $3 \times 5=15$ & $6 \times 3=18$ & 128 \\
\hline 10. & KOTA & $6 \times 5=30$ & $3 \times 4=12$ & $6 \times 3=18$ & $8 \times 2=16$ & $10 \times 1=10$ & $6 \times 5=30$ & $6 \times 3=18$ & 134 \\
\hline 11. & SUHAWAL & $10 \times 5=50$ & $6 \times 4=24$ & $9 \times 3=27$ & $6 \times 2=12$ & $10 \times 1=10$ & $4 \times 5=20$ & $8 \times 3=24$ & 167 \\
\hline 12. & PANWARKALA & $2 \times 5=10$ & $9 \times 4=36$ & $10 \times 3=30$ & $10 \times 2=20$ & $9 \times 1=9$ & $6 \times 5=30$ & $8 \times 3=24$ & 159 \\
\hline 13. & KHANDHU & $9 \times 5=45$ & $9 \times 4=36$ & $8 \times 3=24$ & $7 \times 2=14$ & $10 \times 1=10$ & $8 \times 5=40$ & $8 \times 3=24$ & 193 \\
\hline 14. & UPARWAR & $10 \times 5=50$ & $6 \times 4=24$ & $9 \times 3=27$ & $6 \times 2=12$ & $10 \times 1=10$ & $4 \times 5=20$ & $8 \times 3=24$ & 167 \\
\hline 15. & KUSHA & $8 \times 5=40$ & $7 \times 4=28$ & $8 \times 3=24$ & $6 \times 2=12$ & $10 \times 1=10$ & $6 \times 5=30$ & $8 \times 3=24$ & 168 \\
\hline
\end{tabular}

Table 4. DRASTIC INDEX (pollution potential) of the study area 


\begin{tabular}{|c|c|c|c|c|c|c|c|c|c|}
\hline 16. & NONARI & $3 \times 5=15$ & $6 \times 4=24$ & $4 \times 3=27$ & $7 \times 2=14$ & $10 \times 1=10$ & $6 \times 5=30$ & $8 \times 3=24$ & 144 \\
\hline 17. & HARDOLI & $10 \times 5=50$ & $6 \times 4=24$ & $9 \times 3=27$ & $6 \times 2=12$ & $10 \times 1=10$ & $4 \times 5=20$ & $8 \times 3=24$ & 167 \\
\hline 18. & PANWARKHURD & $9 \times 5=45$ & $9 \times 4=36$ & $10 \times 3=30$ & $8 \times 2=16$ & $10 \times 1=10$ & $6 \times 5=30$ & $10 \times 3=30$ & 197 \\
\hline 19. & PANTI & $8 \times 5=40$ & $7 \times 4=28$ & $8 \times 3=24$ & $6 \times 2=12$ & $10 \times 1=10$ & $6 \times 5=30$ & $8 \times 3=24$ & 168 \\
\hline 20. & KANTI 61 & $5 \times 5=25$ & $3 \times 4=12$ & $7 \times 3=21$ & $8 \times 2=16$ & $9 \times 1=9$ & $5 \times 5=25$ & $5 \times 3=15$ & 123 \\
\hline 21 & PARARHA & $9 \times 5=45$ & $8 \times 4=32$ & $8 \times 3=24$ & $7 \times 2=14$ & $9 \times 1=9$ & $4 \times 5=20$ & $10 \times 3=30$ & 174 \\
\hline 22. & LATIYAR & $10 \times 5=50$ & $9 \times 4=36$ & $10 \times 3=30$ & $8 \times 2=16$ & $10 \times 1=10$ & $6 \times 5=30$ & $9 \times 3=27$ & 199 \\
\hline
\end{tabular}

If D.I.>199; Very high, Between 160 and 199; High, Between 124 and 197; Intermediate, Lower than 124; Low pollution susceptibility.

The various parameters are discussed below:

In the area, the water table varies between 03 to 10 meters, hence the rating should be between 02 to 08 in sandstone and 08 to 10 in shale and the weight parameter is 05 . It indicates the amount of water per unit area of land that penetrates the ground surface and reaches water table. The assigned weight for this parameter is 4 . The net recharge in the area as determined by the water table fluctuation method is. The rating for this recharge is 3 . The bedding planes, joint planes and fractures developed in sandstones and shale. Primary porosity and permeability are insignificant. The rating may be assigned a value of 2 to 5 in sandstone and 06 to 09 in shale. The ratings for aquifer media depend upon the type of consolidated and unconsolidated medium which serves as an aquifer.

In general, the less the clay shrinks and swells, and the smaller the grain-size, the less the pollution potential. The weight assigned to this grain-size, the less the pollution potential. The weight assigned to this parameter is 2 . Thickness and types of soils in the area vary from place to place. There are areas where soil thickness is negligible while in others it goes up to 2 meters. The soil type varies from sandy loam to salty or clayey loam. Hence ratings may be taken as 10, 6, 5 and 4 for computing pollution index. The hilly tracts have slopes greater than 20 for which the rating is 01 . However, in most places have slopes varying between 2 to 6 degrees for which the rating may be 10 in sandstone and shale and assigned weight for this parameter is 01 .

The material present in this zone either facilitate pollution are helps in its attenuation. It also controls the time and distance taken by the pollutants to reach the zone of saturation. In the area, the vadose zone is mainly composed shales and sandstone. Jointing and fracturing are present in rocks. For this the rating may be 3 for shale and 6 for jointed sandstone and assigned weight is 5.It refers to the ability of the aquifer to transmit water under a given hydraulic gradient. The rate of flow within an aquifer controls the movement of contaminants from one place to another. From the computed values, it is observed that the DRASTIC Index varies between 124 to 192 in sandstone aquifer whereas 123 to 199 in shale aquifer. The values suggest the sandstone aquifer have intermediate pollution susceptibility whereas shale aquifer is highly susceptible to pollution.

\section{Conclusion}

The result of geochemical analyses of groundwater samples indicate overall alkaline nature of groundwater. The groundwater with $\mathrm{pH}$ above maximum desirable limit can affect the mucous membrane. The higher values of electrical conductance in shale aquifer may be due to enough time for reaction between groundwater and impervious shale whereas sandstone aquifer has comparatively lesser amount of EC are due to its hydrological characters. About $90 \%$ of samples have TDS less than $1000 \mathrm{mg} / \mathrm{l}$; hence suitable for drinking. As per classification, most of the samples are normal chloride, normal carbonate, normal sulphate and moderate to very hard in nature. The samples plotted on Chadha's diagram indicate that $55 \%$ are $\mathrm{Ca}-\mathrm{Mg}-\mathrm{HCO}_{3}$ type whereas $45 \%$ are $\mathrm{Ca}-\mathrm{Mg}-\mathrm{Cl}-\mathrm{SO}_{4}$ type. The concentration of sulphate associate with shale aquifer is high due to gypsum $\left(\mathrm{CaSO}_{4} 2 \mathrm{H}_{2} \mathrm{O}\right)$ and baryte $\left(\mathrm{BaSO}_{4}\right)$ nodules present in shale. The source of sodium and potassium ions may be the feldspar and clay minerals associate with aquifers. In few samples, concentration of fluoride is high due to presence of $\mathrm{F}^{-}$bearing minerals (muscovite, biotite and clay). The deflouridation and ion exchange techniques may be adopted in high fluoride localities. The comparison of analysed data with WHO (1984) and ISI (1991) indicate that groundwater samples of the area are more or less suitable for drinking.

The groundwater samples have also been evaluated for their irrigation quality. The plot of sodium percentage vs electrical conductance of groundwater samples of the study area suggest that $55 \%$ samples are excellent to good category whereas $45 \%$ samples are in good to permissible category. The samples plotted in U.S. salinity diagram suggest medium to high saline and low alkaline nature. The water having high salinity should be used only in 
those soils where adequate drainage is available. The calculated values of corrosivity ratio suggest that $84 \%$ samples are safe whereas $16 \%$ samples are corrosive in nature and need non-corrosive pipe for transporting and lifting of groundwater. The other parameters such as Kelley's Ratio, Residual sodium carbonate, Magnesium Ratio, Permeability Index suggest that groundwater of the study area are suitable for irrigation purpose.

The computed Drastic Index (Index of Vulnerability) varies between 124 to 192 in sandstone aquifer whereas 123 to 199 in shale aquifer. The values suggest the sandstone aquifer have intermediate pollution susceptibility whereas shale aquifer is highly susceptible to pollution. In the high pollution susceptibility zone, the dug well need to have properly constructed which will present waste water from percolating into the well. The use of pesticides and insecticides in agriculture sector should be avoided. Besides these, proper attention and water quality monitoring programme is needed to check the groundwater pollution.

\section{References}

Ahmed, S. S., Mazumder, Q. H., Jahan, C. S., \& Islam, A. (2002). Hydrogeochemistry and classification of groundwater, Rajshahi city, Bangladesh. Jour. Geo. Soc. India, 60(4), 411-418.

Aller, L., Lehar, J. H., Petty, \& Benett, T. (1987). DRASTIC. A standardised system to Evaluate Groundwater Pollution Potential using Hydrogeological settings. Jour. Geol. Soc. India, Special, 29, 23-37.

APHA. (1998). Standard methods for the examination of water and waste water (14 ${ }^{\text {th }}$ ed.). Washington D.C.: American Public Health Association.

Ayers, R. S., \& Bronson, R. L. (1975). Guidelines for Interpretation of Water quality for Agriculture, Univ. of California, Exension Mimeographed, 13p.

Chadha, D. K. (1999). A proposed new diagram for geochemical classification of natural waters and interpretation of chemical data. Hydrogeology Journal, 7, 431-439. http://dx.doi.org/10.1007/s100400050216

Chatterjee, A., Roy, R. K., Ghosh, U. C., Pramanik, T., Kabi, S. P., \& Biswasm, K. (2008).Fluoride in water in parts of Raniganj Colfield, West Bengal. Current Science, 94, 309-311.

Domenico, D. A., \& Schwartz, F. W. (1990). Physical and chemical Hydrogeology. NewYork: John wiley and sons. pp. 410-420.

Doneen, L. D. (1962). The influence of crop and soil on percolating water. Proc. 1961 Biennial conference on Groundwater Recharge, pp.156-163.

Duraiswamy, R. A., \& Patankar, V. (2011). Occurrence of floride in the Drinking Water sources from Gad River, Basin, Maharashtra. Geol. Soc. India, 77, 167-174. http://dx.doi.org/10.1007/s12594-011-0020-9

Eaton, E. M. (1950). Significance of carbonate in irrigation water. Soil Science, 69, 123-133. http://dx.doi.org/10.1097/00010694-195002000-00004

Hem, J. D. (1985). Study and Interpretation of the Chemical characteristics of Natural Water. U.S. Geol. Surv. Water supply paper-2254, $264 \mathrm{p}$.

ISI. (1991). Indian standard specification for drinking water. IS: 10500, Indian Standard Institution, pp.1-5.

Jasrotia, A. S., \& Singh, R. (2007). Hydrochemistry and groundwater quality around Devak and Rui watershed of Jammu Region, Jammu and Kashmir. Jour. Geol. Soc. India, 69, 1042-1054.

Karanth, K. R. (1987). Groundwater Assessment Development and Management. New Delhi: Tata McGraw Hill Publishing Company Ltd. 725p.

Kelley, W. P. (1951). Alkali soils-their formation properties and reclamation. New York: Reinold Publ. Corp.

Madhnure, P., Sirsikar, D. Y., Tiwari, A. N., Ranjan, B., \& Malpe, D. B. (2007). Occurence of fluoride in the groundwaters Pandharkawada area, Yawatmal district, Maharastra, India. Curr. Sci, 92(5), 675-679.

Mishra, U. K. (2010). Hydrogeological Studies of Sirmour area, Rewa District, Madhya Pradesh.Unpubl. Ph.D. Thesis, A. P. S. Univ. Rewa, M.P., 173p.

Paliwal, K. V. (1972). Irrigation with Saline Water. LA.R.L Monograph, NO.02 (New Series), New Delhi, $198 \mathrm{p}$.

Pandian, K., \& Sankar, K. (2007). Hydrochemistry and groundwater quality in the Vaippar river basin, Tamil Nadu. Jour. Geol.Soc. India, 69, 970-982.

Piper, A. M. (1953). A graphic procedure in the Geochemical Interpretation of Water Analysis. U.S.G.S. 
Ground Water. Note 12.

Pophare, A. M., \& Dewalkar, M. S. (2007). Groundwater quality in Eastern and Southeastern parts of Rajura Tehsil, Chandrapur District, Maharastra. Gond. Geol. Magz. Spec., 11, 119-126.

Purushottam, D., Narsing Rao, A., Ravi Prakash, M., Ahmed, S., \& Babu, A. G. (2011). Environmental impact on groundwater of Maheshwaram watershed, Ranga Reddy District, Andhra Pradesh. Jour. Geol. Soc. India, 77(6), 539-548. http://dx.doi.org/10.1007/s12594-011-0053-0

Raghunath, H. M. (1987). Ground water. New Delhi: Wiley Eastern Ltd. pp.59.

Raman, Y. (1985). Impact of corrosion in conveyance and distribution of water. Jour. I. W. W. A., XV(II), $115-12$

Ramteke, D. S., \& Moghe, C. A. (1986). Manual on water and waste water analysis. NEERI, Nagpur, 340p.

Richard, L. A. (1954). Diagnosis and Improvement of Saline and alkaline soils, USDA. Handbook 160p. Sawyer, C. N., \& McCarty, P. L. (1967). Chemistry for sanitary engineers ( $2^{\text {nd }}$ ed.). New York: McGraw Hill. pp.518.

Ryner, J. W. (1944). A new index for determining amount of calcium carbonate scale formed by a water. Jour. Amer. W. W. Assoc., 36, A72-486.

Saxena, V. K., \& Ahmed, S. (2001). Dissolution of fluoride in groundwater. A water-rock interaction study. Environ. Ged., 40, 1084-1087. http://dx.doi.org/10.1007/s002540100290

Schoeller, H. (1962). Les eaux Souterranies, Massow and cie Paris, 642p.

Suresh, M., Gurugnanam, B., Vasudevan, S., Dharanirajan, K., \& Raj, J. N. (2010). Drinking and irrigational Feasibility of groundwater, GIS spatial mapping in upper Thirumanimuthar sub basin Cavery River,Tamil Nadu. Jour. Geol.Soc. India, 75(3), 518-526. http://dx.doi.org/10.1007/s12594-010-0045-5

Tiwari, R. N., \& Dubey, D. P. (2007). Petrography, diagenesis and depositional environments of Govindgarh Sandstone of Rewa Group, Vindhyan Supergroup, Madhya Pradesh. Gond. Geol. Magz., 22(2), 11-16.

Tiwari, R. N., Bharti, S. L., \& Mishra, Umesh. (2010). Hydrogeochemical Studies of Groundwater from Odda River Basin, Rewa District, Madhya Pradesh. Gondwana Geological Magazine, Special(12), 85-93.

Tiwari, R. N., Dubey, D. P., \& Bharti, S. L. (2009). Hydrogeochemistry and groundwater quality in Beehar River Basin, Rewa district, Madhya Pradesh, India. Inter. Jour. Earth Eng. Sci., 2(4), 324-330.

U.S. Salinity Laboratory Staff. (1954). Diagnosis and Improvement of Saline and Alkali Soils. U.S. Deptt. Agriculture, Handbook, 160 p.

Walton, W. C. (1970). Groundwater resources evaluation. New York: Mc-Graw Hill Book Company. $664 \mathrm{p}$.

WHO. (1984). Guidelines to Drinking water quality. World Organisation Geneva, 186p.

Wilcox, L. V. (1955). Classification and use of irrigation waters. U.S. Deptt. of Agriculture cire, 969, Washington, D.C., pp.19. 